\title{
PERAN AKSES E-JURNAL INTERNASIONAL UNTUK PARA MAHASISWA SELAMA MASA WORK FROM HOME
}

\author{
Prasetyo Adi Nugroho \\ Perpustakaan Universitas Airlangga \\ prasetyo.adi@staf.unair.ac.id
}

\begin{abstract}
ABSTRAK
Pandemi Covid-19 benar benar mengubah tatanan hidup sebagian besar masyarakat di Indonesia. Selama masa PSBB, semua instansi pendidikan baik sekolah, balai diklat, tempat kursus, maupun universitas meliburkan kegiatan belajar mengajar yang selama ini dilaksanakan dengan tatap muka dikelas. Akses E-jurnal bisa menjadi salah satu solusi untuk mengatasi kendala keterbatasan akses literatur pada pendidikan tinggi. Studi ini bertujuan untuk menjelaskan akses E-jurnal bagi para akademisi. Studi ini menggunakan metode kualitatif. Data dikumpulkan dengan studi kepustakaan. Temuan data selanjutnya dianalisis dengan pendekatan analisis deskriptif. Hasil studi menunjukkan bahwa akses Ejurnal tidak hanya didapat dari berlangganan jurnal, tapi juga dari artikel buatan akademisi yang telah dipublikasikan oleh jurnal tujuan. Selain itu, open access memberikan kemudahan bagi para akademisi dalam menambah literatur yang mereka butuhkan, sehingga bisa melewati situasi work from home dengan tetap produktif.
\end{abstract}

Kata Kunci : koleksi digital, perpustakaan, pandemi

\section{PENDAHULUAN}

Pandemi Covid-19 benar-benar mengubah tatanan hidup sebagian besar masyarakat di Indonesia. Masyarakat dihimbau tidak hanya untuk mentaati protokol kesehatan seperti menjaga jarak dan menjaga kebersihan, tetapi juga melaksanakan kegiatan dirumah (Setiati and Azwar, 2020). Pemerintah pusat dan daerah mengeluarkan kebijakan seperti pembatasan sosial berskala besar atau PSBB dimana masyarakat dilarang untuk berkumpul ditempat umum dan melaksanakan kegiatan belaar mengajar serta pekerjaan dirumah. Hal ini dilakukan untuk mengurangi jumlah mata rantai penyebaran kasus Covid-19 di Indonesia, sehingga jumlah korban jiwa bisa diminimalisir (Suryahadi et al., 2020).

Selama masa PSBB, semua instansi pendidikan baik sekolah, balai diklat, tempat kursus, maupun universitas meliburkan kegiatan belajar mengajar yang selama ini dilaksanakan dengan tatap muka dikelas. Penutupan semua sekolah di DKI serta di beberapa kota lainnya di Indonesia, membuat tantangan baru baik bagi para pendidik maupun orang tua dan wali murid yang sekarang belajar dari rumah (Syamsuddin et al., 2020). Salah satu upaya untuk mengatasi hal tersebut yakni dengan menyeragamkan semua mata pelajaran sesuai dengan jenjang masing masing dan menayangkannya pada saluran televisi TVRI. Hal ini 
dilakukan oleh Mendikbud DIKTI untuk menjangkau semua lapisan masyarakat agar dapat tetap mengenyam pendidikan walaupun terkendala fasilitas digital (Wajdi et al., 2020).

Berbeda dengan pendidikan dasar dan menengah, pendidikan tinggi justru menyelenggarakan semua bentuk perkuliahan lewat daring atau tatap muka secara online. hanya perkuliahan yang membutuhkan praktek di laboratorium masih bisa dilaksanakan dengan tatap muka, namun masih mengikuti protokol kesehatan. Pendidikan tinggi dirasa cukup dengan daring saja tanpa tatap muka di kelas karena tidak semua materi perkuliahan harus disampaikan lewat tatap muka dan mengikuti alur textbook (Pakpahan and Fitriani, 2020). Berbeda dengan pendidikan dasar dan menengah yang menjadikan textbook tiap mata pelajaran sebagai acuan dasar untuk naik kelas, textbook hanya sebagai referensi bagi pendidikan tinggi, dan lebih banyak kegiatan yang mengacu pada berpikir kritis dan pengembangan ilmu, sehingga tidak semua mata kuliah harus dilakukan secara tatap muka. Mahasiswa bebas mengembangkan kreasi mereka setelah mendapatkan pengetahuan dasar baik dari daring maupun catatan dari dosen lewat E-mail (Purwanto et al., 2020).

Perpustakaan sebagai jantung dari akademisi memiliki peran penting dalam membantu mahasiswa untuk menambah referensi mereka. tentunya tidak semua perkuliahan bisa tercukupi hanya dengan pengetahuan dari daring ataupun catatan dosen. Butuh referensi dari literatur maupun buku koleksi dari perpustakaan sesuai bidang ilmu mereka. namun akibat dari diberlakukannya PSBB, semua perpustakaan terpaksa menutup layanan mereka dan menggantinya dengan akses repository secara online (Salahudin et al., 2020). Beberapa perpustakaan universitas bahkan menyediakan akses jurnal bereputasi internasional secara gratis bagi para mahasiswanya. Pihak perpustakaan berlangganan pada penerbit jurnal tersebut, sehingga bisa membantu para akademisi mereka untuk mengatasi kesulitan dalam pencarian referensi yang dibutuhkan selama masa pandemi (Ratnasari and Sensuse, 2017).

Perpustakaan universitas Airlangga juga berlangganan beberapa jurnal internasional sesuai dengan kebutuhan masing masing fakultas. Hal ini dilakukan agar mahasiswa bisa dengan mudah mendapatkan acuan informasi untuk tugas mata kuliah mereka, referensi untuk tugas akhir, maupun sebagai pedoman bagi kegiatan penelitian dan praktikum. Berdasarkan latar belakang tersebut studi ini bertujuan untuk mengobservasi peran layanan E-jurnal bagi para akademisi, khususnya mahasiswa universitas Airlangga.

\section{TINJAUAN PUSTAKA}

\section{Transformasi Koleksi Perpustakaan pada Era Digital}

Pustakawan harus selalu mengikuti perkembangan zaman agar bisa mengantisipasi kebutuhan yang mungkin muncul pada tahun tahun berikutnya. Perpustakaan modern harus dikelola sesuai dengan praktik modern, dengan mempertimbangkan kekuatan pasar dan iklim ekonomi saat ini. Pada lingkungan pendidikan tinggi, perpustakaan dituntut untuk menyesuaikan koleksi mereka agar bisa meningkatkan kreativitas mahasiswa, sumber pendanaan yang terbatas serta permintaan informasi yang semakin beragam menyebabkan perpustakaan untuk mengubah cara kerja mereka. Salah satu langkah tersebut yaitu penyediaan akses repository berbasis digital (Kolesnykova, 2017). 
Penambahan koleksi secara digital disebut sebagai cara untuk mengatasi minimnya akses perpustakaan untuk masyarakat. Koleksi digital tidak membutuhkan ruang yang besar dan perawatan yang mahal layaknya koleksi cetak. Selain itu koleksi digital bisa menyesuaikan perkembangan zaman dimana permintaan informasi para pemustaka cenderung mengikuti trend dan sulit untuk dipenuhi hanya dengan berbekal koleksi cetak (Seeman, 2018). Ketersediaan buku dan literatur juga menjadi kendala pada koleksi cetak dimana buku yang terbatas menyebabkan tidak semua pemustaka dapat meminjam buku dengan informasi sesuai yang mereka inginkan. Hal ini tidak berlaku pada koleksi digital dimana buku berbentuk PDF bisa diakses dan didownload oleh akademisi manapun, selama mereka diberi akses oleh pihak universitas (Wilson and Humphrey, 2017).

\section{METODE PENELITIAN}

Studi ini menggunakan metode kualitatif dikarenakan tergolong sebagai studi kepustakaan tanpa menggunakan responden atau makhluk hidup sebagai sampel penelitian. Data dikumpulkan melalui kajian pustaka dan pencarian artikel berbasis digital untuk menambah referensi yang dibutuhkan. Data primer penelitian ini meliputi layanan akses repository perpustakaan Universitas Airlangga pada langganan jurnal internasional seperti SAGE, WILEY, JSTOR, ELSEVIER, CAMBRIDGE, PROQUEST, ACS Publication, dan Wolter Kluwer (Wardhana, 2020). Data sekunder penelitian ini meliputi artikel tentang ilmu perpustakaan dan medis mengenai dampak covid 19 pada masyarakat untuk menganalisis temuan pada studi ini. Data dianalisis dengan menggunakan pendekatan berbasis analisis deskriptif (Seeman, 2018).

\section{PEMBAHASAN}

\section{Dampak Pandemi Covid 19 bagi Pemustaka}

Pandemi Covid 19 dikenal sebagai penyakit mematikan yang telah merenggut jutaan jiwa diseluruh dunia. Penyakit ini masih berbahaya bagi masyarakat karena belum ditemukan obat yang cocok untuk mengatasi gejala yang timbul akibat virus Covid 19 maupun adanya vaksin untuk mengatasi penyakit ini. Pemerintah Indonesia telah memberlakukan karantina masal bagi masyarakat yang positif terinfeksi Covid 19 ataupun mempunyai hasil pada Rapid atau Swap tes positif. Pemerintah daerah telah membatasi larangan berkumpul dan meliburkan seluruh instansi pemerintah serta membatasi akses masuk ke kota besar demi mengurangi penyebaran wabah ini (Setiati and Azwar, 2020).

Akibat diberlakukannya pembatasan tersebut, akademisi khususnya mahasiswa kesulitan untuk mendapatkan akses literatur yang diperlukan. Mahasiswa yang menjalani semester akhir dalam menyusun tugas akhir seperti skripsi dan tesis kesulitan untuk menyelesaikan tugas mereka dikarenakan. Hal ini juga berlaku bagi para pengajar khususnya dosen serta para guru di sekolah, yang mana tidak semua mempunyai fasilitas yang memadai untuk melakukan kegiatan belajar mengajar jarak jauh. Studi yang dilakukan oleh Suryahadi et al menggambarkan akibat pandemi Covid 19 terhadap kinerja seperti pada diagaram dibawah ini: 


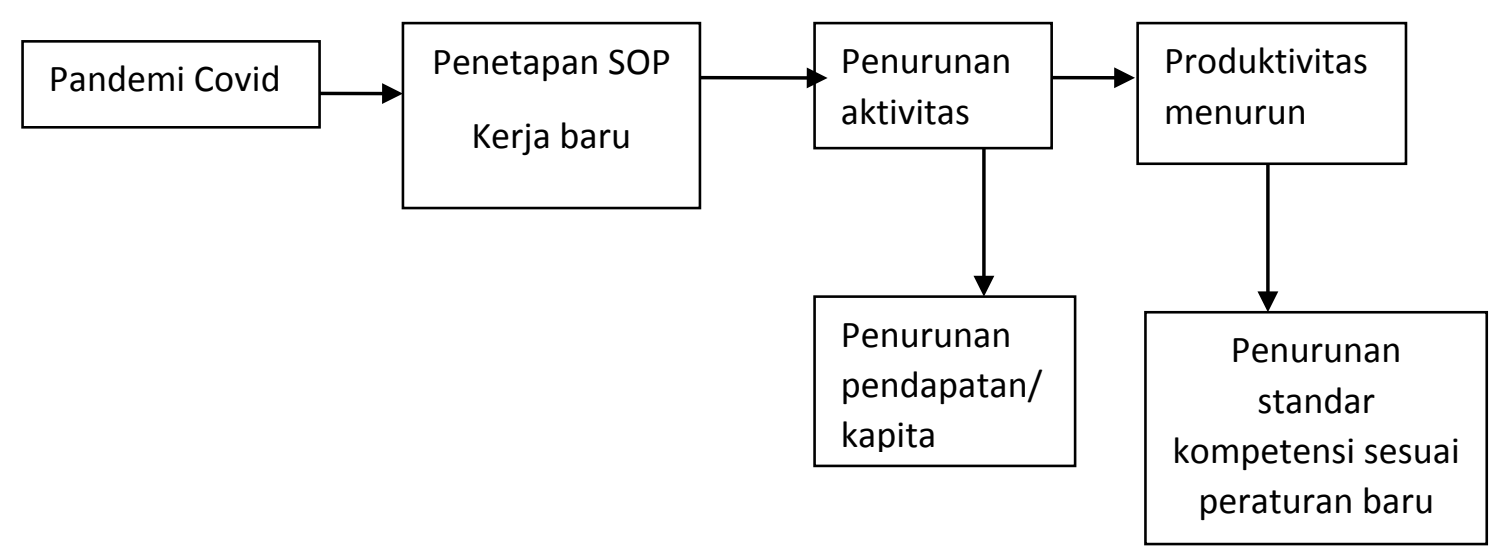

Gambar 1. Pengaruh pandemi terhadap kinerja

Covid 19 mengubah tatanan hidup baru yang menghabiskan biaya lebih banyak dibandingkan sebelum wabah berlangsung, khususnya bagi para pekerja. Bagi para akademisi, keterbatasan fasilitas untuk menunjang pekerjaan mereka membuat pihak sekolah dan perguruan tinggi untuk menetapkan standar kinerja terbaru untuk dikarenakan kendala fasilitas yang terbatas menyebabkan kinerja para akademisi turun secara signifikan (Suryahadi et al., 2020). Selain itu, keterbatasan akses digital pada peserta didik, khususnya yang bertempat pada daerah terisolir atau jauh dari perkotaan mengharuskan pihak pendidik untuk menurunkan standar kompetensi peserta didik mereka secara terpaksa. Namun hal ini jarang terjadi pada pendidikan tinggi karena pakem pendidikan mereka tidak terlalu tergantung dari buku ajar, namun dari penelitian sekitar masyarakat sesuai dengan jurusan masing - masing (Bethune and Korinek, 2020).

\section{Akses E-journal Berbasis Web Langganan Universitas terhadap Akademisi}

E-journal menjadi bahan yang wajib dibaca oleh kalangan akademisi, khususnya bagi mahasiswa. Selain informasi selalu terupdate, E-journal juga memberikan akses yang tidak terbatas bagi para pengguna. E-journal penting bagi para mahasiswa agar bisa memberikan informasi terbaru yang dapat membantu penelitian mereka.

Universitas Airlangga (UNAIR) sebagai salah satu universitas negeri bereputasi internasional di Indonesia juga berlangganan E-journal untuk memenuhi kebutuhan para mahasiswanya. Salah satu cara agar mahasiswa bisa mengakses koleksi E-journal diluar negeri yaitu dengan fasilitas Remote $X$, dimana pihak perpustakaan memberikan akses akun universitas untuk membaca dan mendownload artikel ilmiah pada perangkat digital mahasiswa masing masing. 


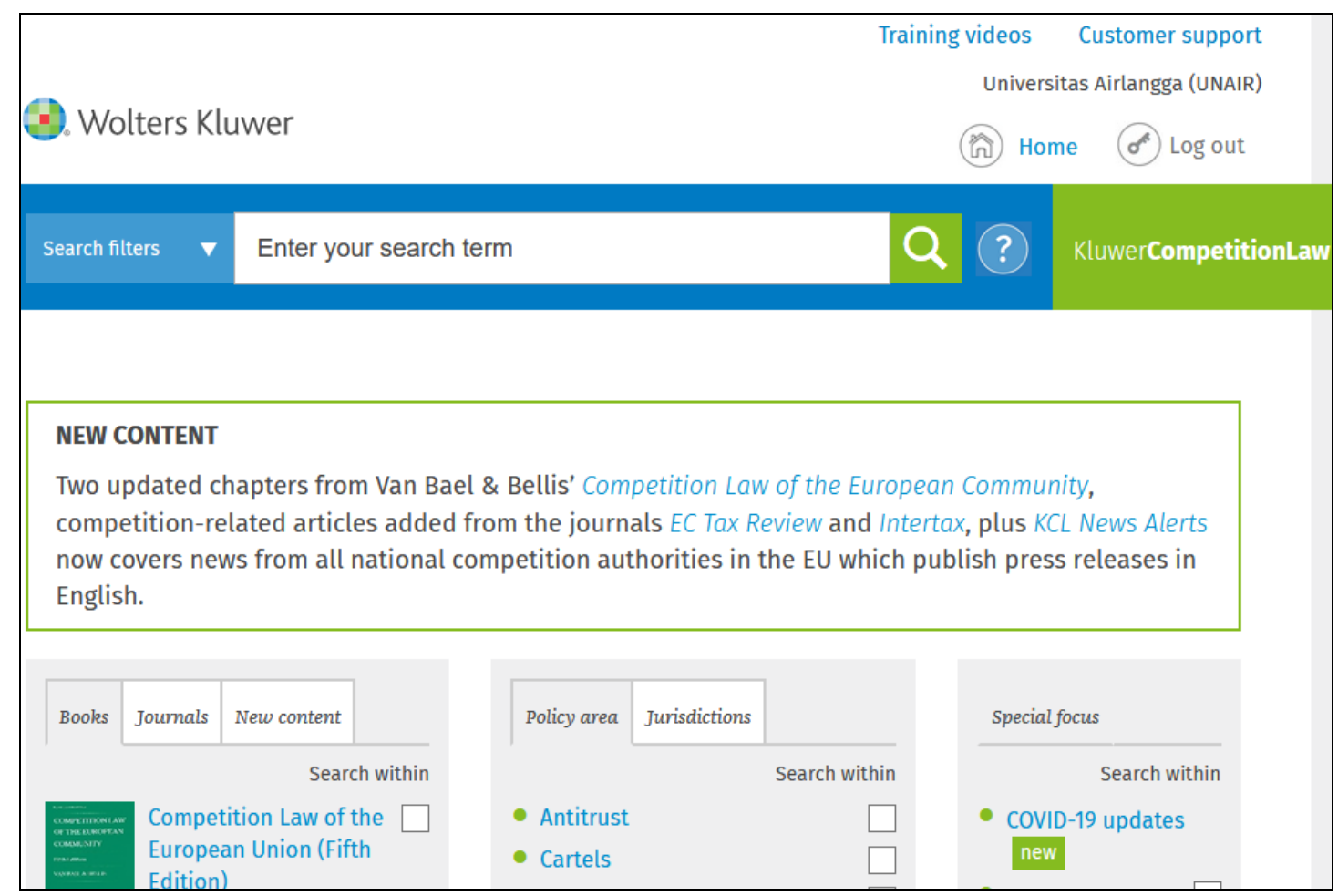

Gambar 2. Salah satu penerbit jurnal yang dilanggankan oleh UNAIR

Salah satu keunggulan akses E-journal untuk para mahasiswa yakni setiap artikel selalu diperbarui dan semakin terkenal suatu penerbit, semakin cepat pula perkembangan artikel yang terbaru. UNAIR mengikuti peraturan dari pemerintah pusat untuk menjadikan index Scopus sebagai acuan dalam menentukan standar kualitas publikasi akademisinya (Ahmar et al., 2018). Oleh karena itu, perpustakaan UNAIR sebagai penyedia kebutuhan informasi dalam Universitas berlangganan beberapa jurnal terindeks Scopus. Salah satunya yakni pada penerbit Wolter Kluwer. Namun tidak semua akademisi bisa memahami konten secara keseluruhan karena jurnal bereputasi internasional menggunakan bahasa Inggris sebagai bahasa pengantar. Butuh setidaknya kemampuan berbahasa yang dibuktikan dengan lulus ujian TOEFL yang nilainya ditentukan oleh pihak universitas (Zein, 2017).

Jurnal bereputasi internasional dapat diakses oleh pihak universitas tidak hanya dengan cara berlangganan, namun juga mengirimkan naskah-naskah para akademisi ke jurnal tujuan dan berhasil diterima untuk diterbitkan. Hal ini disebut juga dengan open access. Ada juga sistem publikasi jurnal hibrid dimana pihak publisher juga menyediakan layanan subscription/langganan bagi para pembaca serta open access bagi para penulis artikel. Menurut studi yang dilakukan oleh Farida et al, universitas bisa mengakses repository $E$ journal berdasarkan kebutuhan para peneliti mereka (Farida et al., 2015). Prosedur akses Ejournal bisa dilihat pada diagram dibawah: 


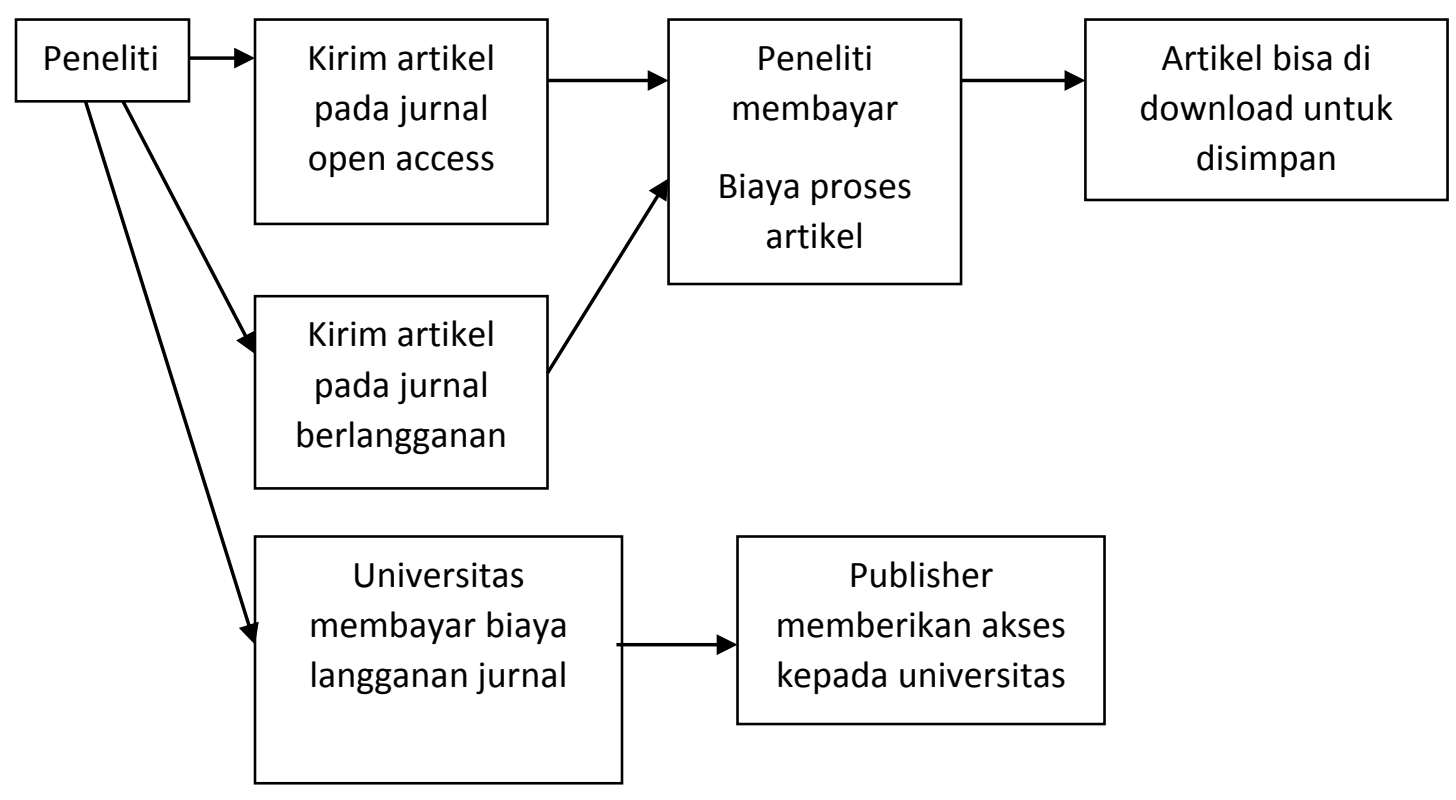

Gambar 3. Alur proses pemberian akses E-journal kepada universitas

Gambar 3 menunjukkan akses E-journal bisa didapat dengan 2 cara yaitu berlangganan jurnal itu sendiri dengan membayar biaya langganan kepada penerbit/publisher, dan mempublikasikan tulisan tulisan akademisi itu sendiri pada jurnal bereputasi internasional. Untuk pembayaran biaya langganan universitas langsung akan diberikan akses selama setahun oleh jurnal yang dilanggankan begitu saja, sehingga akademisi bisa langsung membaca artikel terbaru yang terbit pada halaman jurnal tersebut (Zhang and Watson, 2017).

Artikel yang dikirim oleh akademisi sendiri sebagai penulis dibawah nama universitas, tidak semuanya langsung bisa diakses secara cuma-cuma oleh universitas. Hal ini tergantung dari jenis layanan publikasi oleh jurnal yang dituju. Akses artikel yang terpublikasi dibagi menjadi dua, gold dan green open access. Gold open access membebaskan artikel yang penulis publikasikan bisa dibaca secara bebas tanpa bayar oleh masyarakat pada halaman web jurnal. Sedangkan green open access, hanya penulis yang diberikan akses edisi jurnal yang sudah termasuk artikel miliknya (Levine-Clark et al., 2017).

Gold open access relatif lebih mahal dibandingkan green karena artikel dibebaskan untuk publik, sedangkan green open access artikel bisa untuk komersil para akademisi lain yang harus membayar iuran untuk membaca sebuah artikel. Namun hal ini bisa diatasi dengan mendownload artikel yang sudah terpublikasi pada jurnal green open access untuk repository perpustakaan UNAIR, misalnya, sehingga bisa memenuhi permintaan informasi pemustaka dikala masa work from home seperti sekarang (Gumpenberger et al., 2018). Untuk gold open access, akses artikel yang telah diproduksi oleh akademisi bisa dijadikan bukti pencapaian universitas dalam peningkatan mutu penelitian. Semakin banyak bukti otentik 
pencapaian publikasi ilmiah suatu universitas, semakin tinggi pula reputasi universitas tersebut, baik ditingkat lokal maupun internasional (Jati, 2011).

\section{PENUTUP}

E-journal bisa menjadi solusi dalam mengatasi kekurangan informasi akibat diberlakukannya work from home atau pembatasan sosial. Universitas sebagai pengelola pendidikan tinggi bisa memacu akademisi untuk lebih banyak mempublikasikan karya mereka pada jurnal bereputasi internasional, sehingga semakin banyak akses jurnal yang bisa didapat untuk dibaca. Selain itu, universitas juga bisa langsung berlangganan jurnal sesuai kebutuhan dengan membayar biaya langganan untuk langsung mendapatkan akses E-jurnal. Hal ini bisa semakin meningkatkan kualitas suatu perpustakaan dimana perpustakaan memiliki lebih banyak literatur untuk dikoleksi dan diatur untuk keperluan repository bagi mahasiswa yang membutuhkan.

\section{DAFTAR PUSTAKA}

Ahmar, A.S., Kurniasih, N., Irawan, D.E., Sutiksno, D.U., Napitupulu, D., Setiawan, M.I., Simarmata, J., Hidayat, R., Abdullah, D., Rahim, R., 2018. Lecturers' understanding on indexing databases of SINTA, DOAJ, Google Scholar, SCOPUS, and Web of Science: A study of Indonesians. Journal of Physics: Conference Series. IOP Publishing, p. 12026.

Bethune, Z.A., Korinek, A., 2020. Covid-19 infection externalities: Trading off lives vs. livelihoods. National Bureau of Economic Research.

Farida, I., Tjakraatmadja, J.H., Firman, A., Basuki, S., 2015. A conceptual model of Open Access Institutional Repository in Indonesia academic libraries: Viewed from knowledge management perspective. Libr. Manag. 36, 168-181.

Gumpenberger, C., Hölbling, L., Gorraiz, J.I., 2018. On the Issues of a "corresponding author" field-based monitoring approach for Gold Open Access publications and derivative cost calculations. Front. Res. Metrics Anal. 3, 1.

Jati, H., 2011. Web Impact Factor: a webometric approach for Indonesian universities. International Conference on Informatics for Development. pp. 74-77.

Kolesnykova, T.O., 2017. "I light my candle from your": Anthropological aspects of modern library services for scientists. Anthropological Measurements Of Philosophical Research.

Levine-Clark, M., McDonald, J., Price, J., 2017. Access to Freely Available Journal Articles: Gold, Green, and Rogue Open Access Across the Disciplines.

Pakpahan, R., Fitriani, Y., 2020. Analisa Pemanfaatan Teknologi Informasi dalam 
Pembelajaran Jarak Jauh di Tengah Pandemi Virus Corona Covid-19. Journal of Information System, Applied, Management, Accounting and Research. 4, 30-36.

Purwanto, A., Pramono, R., Asbari, M., Hyun, C.C., Wijayanti, L.M., Putri, R.S., 2020. Studi Eksploratif Dampak Pandemi COVID-19 Terhadap Proses Pembelajaran Online di Sekolah Dasar. EduPsyCouns: Journal of Education, Psychology and Counseling. 2, 112.

Ratnasari, W., Sensuse, D.I., 2017. Analysis of factors affecting users continuance intention of e-resources at the University of Indonesia library: IEEE Xplore Digital Library case study, in: 2017 International Conference on Advanced Computer Science and Information Systems (ICACSIS). IEEE, pp. 53-60.

Salahudin, A.N., Sulistyaningsih, T., Lutfi, M., Sihidi, I.T., 2020. Analysis of Government Official Twitters during Covid-19 Crisis in Indonesia. J. Talent Dev. Excell. 12, 38993915.

Seeman, C., 2018. When is a Library No Longer a Library? The Future of All-Digital Academic Libraries. Passing from 'traditional'to modern. Chicago: Acrl University Libraries Section (Uls).

Setiati, S., Azwar, M.K., 2020. COVID-19 and Indonesia. Acta Med. Indonesia. 52, 84-89.

Suryahadi, A., Al Izzati, R., Suryadarma, D., 2020. The Impact of COVID-19 Outbreak on Poverty: An Estimation for Indonesia. SMERU Working Paper.

Syamsuddin, S., Ahmad, H., Afriani, A., 2020. Media Pembelajaran Online terhadap Kemampuan Berpikir Tingkat Tinggi Matematika di Tengah Pandemi Covid-19. Pepatudzu: Media Pendidikan dan Sosial Kemasyarakatan 16, 41-50.

Wajdi, Muh \& Ubaidillah, Burhanuddin \& Mulyani, Sri \& Anwar, Khoirul \& Istiqomah, Lailatul \& Rahmawati, Fauziyah \& Hikmawati, Sholihatul \& Ningsih, Diah \& Rizal, Hasan. (2020). Pendampingan Redesign Pembelajaran Masa Pandemi Covid-19 bagi Tenaga Pendidik di Lembaga Pendidikan berbasis Pesantren di Jawa Timur. Jurnal Pengabdian Kepada Masyarakat. 4. 266-277. 10.29062/engagement.v4i1.193.

Wardhana, A.K., 2020. Information search trends about sharia: a comparation study between business-industry genre with book-literature genre. J. Halal Prod. Res. 3, 3542.

Wilson, E., Humphrey, J., 2017. Successfully transitioning the world's largest chemistry subscription journal to a gold open access publication. Insights 30 .

Zein, M.S., 2017. Elementary English education in Indonesia: Policy developments, current practices, and future prospects: How has Indonesia coped with the demand for teaching English in schools?. English Today 33, 53-59.

Zhang, L., Watson, E.M., 2017. Measuring the impact of gold and green open access. $J$. Acad. Librariansh. 43, 337-345. 